\title{
Crisis Response Strategies of political parties in the Egyptian Social Media- the Constitutional Declaration as a Case Study
}

\author{
Dr. Inas A. Hamid El-Khoreiby ${ }^{(*)}$
}

\section{Introduction}

Over the past ten years, a rapidly growing body of crisis management research has emerged focusing on organizations' behavior within times of crises.

Communication scholars have increasingly focused on communication's role in crises times as they discovered its importance in reducing uncertainty about the causes of the crisis, its consequences and protecting its reputation. Also, they emphasized on "the importance of explaining provided information about the crisis, finding its roots and presenting opinions of decision makers toward the crisis" (Sayed, 2000: 43). Many researchers argued that crisis communication should extend to include dialogue between the organization and its publics prior to and after the crisis (Jin, Pang \& Cameron, 2010: 428).

As there are many studies that are focused on Crisis Management Strategies in commercial organizations, it is also important to conduct such studies when political crises arouse in any society. Many researchers and political experts argue that the "outcome of political conflicts depends heavily on the strategies adopted by members of parties to the conflict, particularly political actors at the elite level, such as government officials, party activists and negotiators" (Golec \& Federico, 2004: 750).

No one can ignore the effect of hiding important information in maximizing the negative effects within times of political crises,

${ }^{(*)}$ Faculty of Mass Communication, Ahram Canadian University 
Crisis Response Strategies of political parties in the Egyptian Social Media- the Constitutional Declaration as a Case Study

especially with the policy of some media in withholding certain facts regarding their policy. This argument was explained by Megeid's study (2010) that was conducted on a sample of ten journalists working in different newspapers, who all referred to their role as gatekeepers in selecting information that consisted of the editorial policy of the newspapers they work in (Megeid, 2010: 14).

Since Egypt's $25^{\text {th }}$ of January revolution in 2011, Egypt has faced many political crises but the first and the second constitutional declarations were the preludes to one of the strongest political crises that made many politicians assume they were the main reasons to the rebellious movement against the former president, Mohamed Morsi.

\section{Research problem}

Before the Arab revolutions and especially the Egyptian revolution in 2011, most of the Arabic communication studies ignored how different political actors and wings can use the new media in managing crises they faced, especially in countries whose people are still taking their first steps towards political participation, and this was one of the main reasons to conduct this research as it has two goals. First, it intends to explore crisis response strategies (CRSs) that had been implemented by two official political pages on Facebook between the $22^{\text {nd }}$ of November and the $25^{\text {th }}$ of December, a period that began with the Egyptian President Mohamed Morsi's announcement of the first constitutional declaration which claimed to restrict many civil liberties until the issuance of the Egyptian constitution, which triggered controversy and opposition from many political trends on its clauses. Second, the study looks at possible differences within strategies that had been adopted by two different pages, as each of them reflected different political trends that might have led to some differences in their choices of (Crisis Response Strategies) CRSs. 
Crisis Response Strategies of political parties in the Egyptian Social Media- the

Constitutional Declaration as a Case Study

\section{Literature review}

There was growing concern with crisis communication studies in the last decade of the 20th century in contrast to crisis management studies before that period. Crisis communication studies have recently begun to examine how people perceive the crisis response strategies (CRSs) and their effects on their response to the crisis. The following discussion will review studies related to this research in the light of two main domains; crisis response strategies and the use of social media in crises management.

\section{- Crisis Response Strategies}

The Situational Crisis Communication Theory was developed as a research-based guide for selecting crisis response strategies that are appropriate to the characteristics of the crisis situation. Coombs' Situational Crisis Communication Theory (SCCT) suggests that the theory can help crisis managers in the selection of crisis response strategies and/or the effect of crisis response strategies have on organizational reputation" (Sisco \& Erik, 2010:2). The theory advises organizations to prioritize protecting their publics from harm through two strategies; providing instructing and adjusting information. "Instructing information represents what people need and want to know after a crisis hits to protect themselves from physical threats, while adjusting information helps publics to cope with any psychological threats" (Coombs \& Holladay, 2008: 352). Coombs (2006) classified the types of instructing information as "crisis basics that provide people with the basic information about what happened in the crisis event, protection information that deals with what people need to do to protect themselves from harm, and correction information to represent what the organization is doing to correct the problem or prevent a repeat of the crisis" (Coombs, 2006: 246).

The SCCT includes three clusters of crisis types based on individuals' attributions of responsibility to the organization in crisis. "The victim cluster" entails crises with weak attributions of 
Crisis Response Strategies of political parties in the Egyptian Social Media- the Constitutional Declaration as a Case Study

organizational responsibility, "the accidental cluster " involves crises with a certain, but low level of responsibility attribution to the organization and finally the "preventable cluster" which incorporates crises with high perceptions of crisis responsibility (Claeys \& Cauberghe, 2012: 2).

The SCCT matches these crisis types, differing in the amount of organizational responsibility, with three clusters of crisis response strategies (CRSs) which the organizations can use to manage their crisis; "denial strategy option ( denial, shifting the blame , and attack the accuser strategies) can be employed when the challenge is unwarranted" (e.g., a victim crises type) (Claeys \& Cauberghe, 2012: 84). "The diminish response strategy option (excuse and justification) is recommended to reduce organizational responsibility, thus being useful for the accident crisis type that has low crisis responsibility attribution. The rebuilding response strategy option (compensation and apology) is recommended for cases of the preventable crisis type (Sora \& Hoon, 2015:6). Also, Coombs suggested a secondary strategy that can be used as supplements to the previous postures, termed bolstering response strategies, which includes "reminding stakeholders about past works, ingratiation and victimage" (Sisco, 2012: 91). The seven organizational response strategies proposed by SCCT are "attack the accuser, denial, scapegoat, excuse, justification, compensation and apology" (Grebe, 2013: 73).

These strategies vary as "not all of them provide the audiences with the same level of explanation or the protection of the crisis" (Dutta \& Pullig, 2011: 1283). Crisis managers should select the crisis response strategy that matches the amount of crisis responsibility attributed to the organization and the characteristics of the crisis situation. Also the selection is "premised on the reputational threat posed by the crisis situation and the protective properties of the crisis response strategy (ies)" (Coombs, 2006: 242). Many scholars 
Crisis Response Strategies of political parties in the Egyptian Social Media- the Constitutional Declaration as a Case Study

discovered a relationship between the CRSs choices and the organization's perceptions of the crisis' nature. For example Penrose's (2000) study discovered that "Organizations that understood both the threat and opportunity inherent in a crisis tended to engage in planning pre-crisis and post-crisis activities that can lead to effective external communication with the organization's publics" (Vielhaber \& Waltman, 2008: 311).

Although some researchers emphasized the importance of selecting a proper strategy in crises times, White \& Brown (2013) emphasized in their study on the fact that maintaining positive relationships with stakeholders may be more important than using any of crisis strategies (Brown \& White, 2013: 75). At the same time, there was over promotion to the apology strategy in a lot of research, but some researchers proved less effect of it as it has been thought. For example, An (2011) found in his study on a sample of 230 students enrolled in communication courses, that the students showed less blame and anger towards the organization that used the deal strategy by which the organization admitted its responsibility of occurred crises (An, 2011: 170).

\section{- Social media and crises management}

The following discussion revolves around developing an understanding of the role of social media in managing crises especially that social media gives any group in the world the chance to establish its own communication as to "facilitate interactive communication and content exchange among and between publics and organizations, as it proves to be the most reliable source for news, especially ideal for generating timely communication, unique information, and interactive conversations" (Liu, Austin \& Jin, 2011: 346). This importance made the researchers develop a new model of the situational crisis communication theory called the social mediated crisis communication model that focused on the role of social media 
Crisis Response Strategies of political parties in the Egyptian Social Media- the Constitutional Declaration as a Case Study

in managing crises by discussions, answering queries from audiences and updating them with information (Fisher, Austin \& Jin, 2011: 345).

According to Gillis and Johnson's study (2013) that was conducted on a sample of 421 journalists, they reported their use of social media is increasing as they considered it a source of information that contains accurate information, documented expertise of the writer, and evidence of objectivity to be credible. A substantial amount of research has proved the importance of using social media in times of crises by publics, activists, journalists and officials. For example, the social networking site, Twitter, was used during the 2008 California wildfires, the Mumbai massacre and the crash of US Airways Flight 1549 (Veil, Buehner \& Palenchar, 2010:2). Goolsby's study (2010) proved that Twitter users in India "traded information, requested help, looked for people feared to be caught at one of the attack sites, and even documented the situation" during the terrorist attacks on Mumbai in 2008. (Goolsby, 2010:7). Also, Barin in his study (2010) argued the effective role of Twitter in exchanging information and ways of volunteering during Haiti crisis in 2010 in the states (Smith, 2010: 330)

At the same time, many governments and official institutions used social media to connect with their audiences in times of crises and build relationships with them. For example social media was the most popular reference for information that was used by the U.S. Centers for Disease Control and Prevention (CDC) regarding the crisis of H1N1in 2010. Blogs were the most popular type of documents, and Twitter is the most popular source being referenced (Freberg, Palenchar and Veil, 2010).

Also, several studies have shown the power of social media in aiding and supporting citizens in political organization, protest and revolution. No one can ignore the role of social media in supporting the Arab uprising and publicizing it to the world as many of the political scholars and experts backed the Arab revolutions to spread 
Crisis Response Strategies of political parties in the Egyptian Social Media- the

Constitutional Declaration as a Case Study

the use of social media. It succeeded in "linking the voices of protesters inside the country to the outside world; managing messages to bridge the gap between social media and mainstream media, and collaborating with professional journalists and translating messages to fit the contexts and understandings of foreign publics" (Anden \& Pantti, 2013). Social media was used by the Egyptian military council after ousting the Muslim brotherhood in Egypt in June 2013, as it used their official Facebook page to clarify their efforts to overcome terrorism and rumors, present procedures for facilitating the work of journalists, mobilizing the public to support their work and building a positive image of them (Soliman, 2014:155). Shaaban \& Lotfy (2013) proved in their study that was conducted on a sample of 100 of the Egyptian elite with a high rate of social networking use that social media has a vital role in mobilizing demonstrations on the crisis of the Constitution and in addition, Facebook came in first place at providing users with information about the crisis, followed by YouTube and Twitter (Shaaban \& Lotfy, 2013: 294).

\section{Research Questions}

This study seeks to answer the following research questions:

1. What crisis response strategies did both studied parties use to respond to the crisis?

2. Is there any difference between the choices of crisis responses mentioned in official pages posts and the political trend of the page?

3. Did these strategies change over the studied period?

\section{Methods}

This study employed a qualitative content analysis of posted posts of two parties' official Facebook pages. The study investigated the first and second Egyptian constitutional declaration's crisis response strategies (CRSs) that had been implemented by the Freedom and Justice Party and El-Dostor Party between the $22^{\text {nd }}$ of November and the $25^{\text {th }}$ of December 2012. 
Crisis Response Strategies of political parties in the Egyptian Social Media- the Constitutional Declaration as a Case Study

\section{Sample}

The population for the study consists of all posts that were published by the Freedom and Justice Party and the El-Dostor Party on their official Facebook pages from the $22^{\text {nd }}$ of November through to the $25^{\text {th }}$ of December 2012.

- Official Facebook page of the Freedom and Justice Party is a page that was launched in 14 July 2011 after the Egypt's 25th of January revolution and expresses the objectives of the Freedom and Justice Party that focuses on shifting towards freedom, democracy, justice and full human rights.

- The official Facebook Page of the El-Dostor Party was launched on $23^{\text {rd }}$ April 2012 to express the opinions of this party that can be summarized by "life, liberty, social justice and human dignity". The El-Dostor Party was one of the strongest parties that led a campaign to mobilize the Egyptians to oppose the constitutional declaration and the issuance of the Constitution and this is why the study aimed at analyzing its content.

\section{Findings}

The crisis situation

On the $22^{\text {nd }}$ of November 2012 the former elected president of Egypt Mohammed Morsi announced the first constitutional declaration that was followed by the announcement of the second on the $9^{\text {th }}$ of December 2012 and ended with the issuance of the new constitution on the $25^{\text {th }}$ of December 2012. A crisis in the political environment erupted as these declarations claimed to restrict many of the civil liberties and gave the president unlimited authority. It must be noted that the El-Dostor Party considered the two declarations as a violation of the revolution goals and to the level of freedom that should be given to the Egyptians, while the freedom and Justice party considered the declarations as a must in order to achieve stability for the Egyptian 
Crisis Response Strategies of political parties in the Egyptian Social Media- the Constitutional Declaration as a Case Study

society. However, the Freedom and Justice Party claimed that the conflict of opinions expressed by their opponents and within the media resulted in this crisis.

After analyzing posts that were published by the Freedom and Justice Party and El-Dostor Party on their official Facebook pages, the results will be presented with regards to the two stages that the crisis passed through. The first stage $\left(\mathrm{T}^{1}\right)$ started with the release of the first constitutional declaration until the second constitutional proclamation from the $22^{\text {nd }}$ of November till the announcement of the second constitutional declaration in the $8^{\text {th }}$ of December 2012. The second stage $\left(\mathrm{T}^{2}\right)$ started with the release of the second constitutional declaration until the issuance of the Constitution in the period from the $9^{\text {th }}$ of December 2012 till the issuance of the Egyptian new Constitution on the $25^{\text {th }}$ of December 2012.

\section{Freedom and Justice Party page}

Through posts analysis of the Freedom and Justice Party page within the whole studied period, the results indicate that seven posts were published few hours before announcing the first declaration and they used the excitement style by emphasizing a close revolutionary decision that would depend on reviewing the economic, political and safety issues. From my point of view, those posts aimed to win the support of the members of the page to the decisions that had not been issued by focusing on a number of sentences such as "the aspirations of the Egyptian streets, satisfying the public's needs, achieving the revolution's principles and the importance of punishing the killers of the revolutionaries.

The analysis of the first stage related posts $\left(\mathrm{T}^{1}\right)$ indicate that the attack strategy was a frequently used strategy. The posts attacked opposition parties of the declaration as well as some opposition media, and thus blamed them for having prejudgments about the president himself, his decisions, trying to overthrow him and not seeking any solutions for the crisis. They also attacked some of the politicians and 
Crisis Response Strategies of political parties in the Egyptian Social Media- the

Constitutional Declaration as a Case Study

media experts who called themselves the elite and described them as having conflicting statements, they asked for freedom then they refused the declaration. The posts also threw the responsibility for any violence happening in demonstrations that they called for on the opposition political movements' leaders. The posts highlighted some points, such as opponents' intentions of overthrowing and attacking the president personally, rather than his decisions and aligning with revolutionists in order to reinstate the previous military rule.

The scapegoating strategy was also one of the dominant strategies that was used in this stage to blame others for the crisis such as media and opponent parties, as many of the party supporters' posts stated the unwillingness of the media and other political parties to cooperate with the president to find solutions for the critical political situation. The posts also blamed the judiciary for planning a judicial coup. Some posts used the justification strategy as one of the diminish postures, as they justified the declaration and described it as a tool to eliminate Mubarak's regime and his supporters, stop working with the declaration with the issuance of the Constitution, give the president the power to use his authority, achieving stability for the society, a way for correcting the way of the revolution movement, rebuild a revolutionary Egypt, achieving justice and finally, achieve community safety. Some posts stated that Morsi was the least president with authority.

To some extent, the posts used the bolstering strategy to show that the president as a victim of the media and the judiciary who were pushing for the coup to withdraw with the president by attacking his performance and decisions.

Most of the presented information used was such of facts and news to inform the visitors of the page with the new decisions and the acts of the declaration without interpreting them. While the posts focused on demonstrations and movements that supported the constitutional declaration as positive steps to support legislation, they 
Crisis Response Strategies of political parties in the Egyptian Social Media- the Constitutional Declaration as a Case Study

mentioned the opposition movements as aggressive, subversive movements with no justification and funded by the former regime. The site uploaded numerous photos that conveyed these opponents' demonstrations. All what has been quoted represented the views of the party's supporters to the president's decisions from politicians and religious leaders and this limited the role of the page in achieving the balance between the views of the supporters and its objectivity.

The posts also were eager to show the results of the public opinion polls carried out by a number of local and international media such as Al-Gazira Mobasher, Rasd Network and Kolona Khaled Saeed besides the page itself, they were asking for the degree of support for the president's decisions and all of them showed a high degree of support.

Most of the posts focused on the use of the emotional approach as they expressed their anger and accused all the opposition parties of the declaration of their trying to change the Islamic identity of Egypt. The posts tried to spread the spirit of enthusiasm in favor of the president as they discussed the importance of the continued and strong support from all the Egyptians to support the decisions of the revolution. Emotional approach was also used as posts focused on enthusiasm and religious appeals in mobilizing the supporters and attacking the opponents such as highlighting some points; punishing the killers of the revolutionaries, keeping the Islamic identity and achieving safety and justice.

At the end of this stage, the focus was on the demonstrations organized by the opposition parties as a plan to create chaos and violence to influence the outcome of the referendum on the constitution.

The analysis of the second stage related posts $\left(\mathrm{T}^{2}\right)$ indicate that the attack strategy was the dominant strategy as most of posts attacked the media, opposition parties and accused them and opposition leaders of causing a split within the Egyptian society ," 
Crisis Response Strategies of political parties in the Egyptian Social Media- the Constitutional Declaration as a Case Study

Etehadia crisis " and incitement to not participate in the elections of the new constitution. They also focused on rumors spread by media about the results of not voting in favor for the constitution. The posts attacked those who claimed election fraud.

To some extent, the scapegoating strategy was also one of the strategies that was used in this stage to blame opponents of the constitution for committing violence against the supporters and some foreign countries for the un-stability of the Egyptian society. Also, some posts used the justification strategy as one of the diminish postures, as they justified the constitution and described it as a tool to rebuild a revolutionary Egypt and achieve better life for the Egyptians.

Results indicate that posts completely ignored the constitutional declaration crisis and focused on the mobilization of the masses of the people for a 'yes' vote to the Constitutional referendum.

Most of the posts focused on the use of the emotional approach as they tried to spread the spirit of enthusiasm in favor of the constitution as they discussed the importance of the continued and strong support from all the Egyptians to support the it and they focused on the large number of voters in favor to the constitution.

Many of the presented information used was such of explanatory information as it explains the acts of the constitution. The page prepared a campaign to explain the role of the constitution in achieving development. The site uploaded numerous photos that conveyed these opponents' demonstrations and huge mass of supporters. It also explains steps of voting.

Also, the posts in this stage only quoted the views of the supporters whether politicians or parties of the constitution and tried to explain the advantages of its articles by expert supporters. They also focused on the withdrawal of many of the members of opposition parties as a result of their support to the constitution. 
Crisis Response Strategies of political parties in the Egyptian Social Media- the Constitutional Declaration as a Case Study

At this stage the page used some explanatory information as it uploaded a link by which visitors can find the constitution and an explanation of its articles.

The page developed a campaign to explain the role of voting to approve the constitution in order to stabilize life in Egypt.

At the end of this stage, the posts focused on the religious leaders opinions in the need to respect the voting results.

\section{El-Dostor party}

First of all, it must be emphasized that the El- Dostor Party did not face the same crisis faced by the Freedom and Justice Party as the ruling party supporting the declaration, but faced a different crisis as they claimed that the declaration was affecting the level of democracy and the limits of freedom available to the authority. So the official page of the El- Dostor Party used certain crisis response strategies (CRS) to attack the authority and escalate the crisis faced by the ruling party.

The analysis of the first stage related posts $\left(\mathrm{T}^{1}\right)$ indicate that the attack strategy was the only strategy that had been used by the party as one of the denial postures. The posts attacked the ruling regime and accused them of seeking to control the government. Furthermore, the posts blamed the president for the increasing number of deaths due to violence resulting from the rejection of the constitutional declaration. The posts threatened to escalate the crisis until dropping the declaration.

Most of the presented information used was such of explanatory information as it explained the declaration and its consequences. This information has been introduced through the interpretations of those who were responsible for the page in addition to citing the opinions of experts in the field of law and the Constitution. The posts focused on demonstrations and movements that were against the constitutional declaration and focused on places where demonstrations would start, 
Crisis Response Strategies of political parties in the Egyptian Social Media- the Constitutional Declaration as a Case Study

their times and mobile numbers of organizers. At a time in which posts accused the ruling party elimination of conspiracy, they emphasized the importance of the judiciary and its role in the support of democracy. While post editors varied between ElBaradei, head of the El-Dostor party, those who were responsible for the page, supporters of the party and opponents of the declaration, there was no reference to the views of the pro constitutional declaration, thus making the posts biased to only one point of view.

While most of the El-Dostor party posts relied on the use of the rational approach where the posts explained the crisis and its consequences, some of the posts focused on the use of the emotional approach as they expressed their anger and accused the president of being responsible for the violence that was taking place in Egypt as a result of the declaration. Additionally, they played on the heartstrings of the president by asking him to drop the declaration and activate dialogue with all the parties.

The analysis of the second stage related posts $\left(\mathrm{T}^{2}\right)$ indicates a complete ignorance to the declaration as issue with a great focus on discussing the acts of the new constitution. The attack strategy was the only used strategy by the posts as they focused on the mobilization of the masses of the people to reject the Constitution project. The posts continued to accuse the president and his supporters for causing violence within the Egyptian society and decreasing the level of democracy.

The posts focused on the demonstrations organized by the opposition as a way to reject the constitution and they announced the meeting points of the demonstrators. They showed many photos to prove the huge number of demonstrators who opposed the issuance of the constitution.

The page developed two campaigns to achieve their objectives. The first focused on how to vote in the right way by giving voters some instructions and the other used social-based stories to explain the 
Crisis Response Strategies of political parties in the Egyptian Social Media- the

Constitutional Declaration as a Case Study

disadvantages of the articles of the Constitution. The two campaigns aimed at urging people to vote "no" in the election. The posts focused on the use of emotions, using terms of anger when referring to victims of violence. The posts focused on the party's point of views without refereeing to the supporters' point of view which may affect the page neutrality.

\section{Discussion}

The aim of this article is to explore crisis response strategies (CRS) that had been implemented by official Facebook pages of Freedom and Justice Party as the ruling party and the El-Dostor Party as an opposition party, regarding the announcement of the first constitutional declaration on the $22^{\text {nd }}$ of November 2012 by the former president of Egypt Mohammed Morsi. This declaration was accused of igniting a crisis within the political arena as its opponents claimed it restricted many of the civil liberties and gave the president unlimited authority. The research supposes that each page of them is supposed to reflect different political trend that might led to some differences in their choices of CRSs.

The findings of the content analysis produced somewhat widespread numbers of results across the main defined categories (Crisis response strategies, type of information, the media's roles, levels of responsibility, the use of emotion, negatives that might have occurred, and the most highlighted points by the posts).

Crisis Response Strategies; According to the findings the Freedom and Justice Party's official page used the denial and diminish strategies in managing the crisis they faced. The posts in the first stage of the study used most frequently the denial strategy to attack opposition parties to the declaration, as well as some opposition newspapers and political movements' leaders, who blamed them for having prejudgments about the president himself and their unwillingness to cooperate with the president to find solutions for the problem-riddled political situation. 
Crisis Response Strategies of political parties in the Egyptian Social Media- the Constitutional Declaration as a Case Study

The Freedom and Justice Party attempted to diminish the impact of the situation by justifying the declaration as a tool to eliminate the former regime and its supporters, a way for correcting the way of the revolution movement, rebuild a revolutionary Egypt, achieving justice and achieve community safety. By the issuing of the second declaration, the denial strategy was the only used strategy as the posts completely ignored the constitutional declaration crisis and kept accusing the media and opposition leaders of causing a split within the Egyptian society and incitement to not participate in the elections on the new constitution. When analyzing the posts on the official page of the El-Dostor Party page, the denial strategy was the only used strategy in both stages of the study as they attacked the ruling regime and accused it of seeking to control the government. They also accused the president of violence in the Egyptian society and decreasing the level of democracy. The choices of crisis responses mentioned in the official pages' posts of both parties are consistent with the political trend of the page and parties they represent as both pages are expressing and defending the views of each party respectively.

Type of information; While the Freedom and Justice Party posts' basically relied on the physical information as it informed the visitors of the page with the new decisions without interpreting it, most of the El-Dostor Party posts were much more concerned with explanatory information as it explained the declaration and its consequences. All what was quoted in both pages represented the views of the party's supporters without presenting the views of the opponents which affected the objectivity of the posts. While most of the Freedom and Justice Party posts focused on the use of the emotional approach as they expressed their anger and use the religious approach, the ElDostor Party relied more on the use of the rational approach as the posts explained the crisis and its consequences. 
Crisis Response Strategies of political parties in the Egyptian Social Media- the Constitutional Declaration as a Case Study

\begin{abstract}
Although Freedom and Justice Party was the ruling party within this crisis, its page relied heavily on using the emotional-themed approach in their posts as they expressed their anger and accused all the opposition parties of the declaration as trying to change the Islamic identity of Egypt. While the Freedom and Justice Party posts relied on informing the page visitors with new decisions without interpreting them, the El-Dostor Party was concerned with explaining those decisions and this can be explained in the light of the differences between both parties' objectives towards the crisis.
\end{abstract}

\title{
Conclusion
}

It must be emphasized that the El- Dostor Party did not face the same crisis faced by the Freedom \& Justice Party as the ruling party supporting the declaration, but faced a different crisis in that they claimed that the declaration was affecting the level of democracy and the limits of freedom available to those with authority. So, while the official page of the Freedom and Justice Party tried to prove importance of the declaration's issuance and attack the opponents for rejecting it, the official page of the El-Dostor Party used certain crisis response strategies (CRS) to attack the authority and escalate the crisis faced by the ruling party.

This article used the content analysis method to analyze the posts of both pages from the $22^{\text {nd }}$ of November through the $25^{\text {th }}$ of December 2012 that started with the release of the first constitutional declaration on the $22^{\text {nd }}$ of November till the issuance of the Constitution on the $25^{\text {th }}$ of December 2012.

The research supposes that each page is supposed to reflect different political trends that might led to some differences in their choices of CRSs. But the analysis shows that the attack strategy was used by both pages in different ways. It was used by Freedom and Justice Party to attack opposition parties of the declaration, as well as some opposition aligned media which they blamed them for having prejudgments about the president himself, his decisions and trying to 
Crisis Response Strategies of political parties in the Egyptian Social Media- the Constitutional Declaration as a Case Study

overthrow him. The El- Dostor Party used this strategy to attack the ruling regime and accused it of seeking to control the government. Furthermore, the posts attacked the president and accused him of the increased number of deaths due to violence resulting from the rejection of the constitutional declaration.

These results prove what Coombs had proposed. He argued that in a victim situation, organizations should use the deny strategy. In an accident situation, organizations should use the diminish strategy, while in a preventable situation organizations should use the rebuild strategy. Regarding the situation in Egypt discussed here, both parties witnessed themselves as victims. The then ruling party (Freedom and Justice Party) felt that the opponents wanted to overthrough the president, while simultaneously, the El- Dostor Party argued that the declaration restricted many of the civil liberties, thus giving the president unlimited authority.

While the attack strategy was the only CRS that was used by the ElDostor Party, Freedom and Justice Party used another three strategies; the scapegoating, the justification and the bolstering strategies. The scapegoating strategy was used to blame opponents, both media and parties, for the crisis. Also, the justification strategy as one of the diminish postures was used to justify the declaration as a tool to eliminate Mubarak's regime and his supporters, stop working with the declaration with the issuance of the Constitution, give the president the power to use his authorities, a way for correcting the way of the revolution's movement, and rebuild a revolutionary Egypt, all while achieving justice and achieving community safety. The bolstering strategy was also used to depict the president as a victim of the media and the judiciary who were pushing for the coup in order to take out the president by attacking his performance and decisions. Also, the analysis shows that both pages represented the views of the party supporters without presenting the views of the opponents which affected the objectivity of the posts, and this may describe what was 
Crisis Response Strategies of political parties in the Egyptian Social Media- the Constitutional Declaration as a Case Study

said about this crisis as a war between those who supported the president and those who were against him.

While the El- Dostor Party used only the attack strategy within the analysis period, the official page of the Freedom and Justice Party used the strategies in a different manner. At the first stage $\left(\mathrm{T}^{1}\right)$ of the analysis that started with the release of the first constitutional declaration until the second constitutional proclamation from the $22^{\text {nd }}$ of November till the announcement of the second constitutional declaration on the $8^{\text {th }}$ of December 2012, it used three different strategies; attack, scapegoat, justification and bolstering strategies. While at the second stage $\left(\mathrm{T}^{2}\right)$ of the analysis that started with the release of the second constitutional declaration until the issuance of the Constitution in the period from $9^{\text {th }}$ of December 2012 till the issuance of the new Egyptian Constitution on the $25^{\text {th }}$ of December 2012, it only used the attack strategy and this can be explained as a result of the severe attack that was directed towards the president and his party. In conclusion, this article proved that there is no difference between the choices of crisis responses mentioned in official pages posts of both parties and their political trend as each defended the position of the party and attacked the other party as one of its opponents. 
Crisis Response Strategies of political parties in the Egyptian Social Media- the Constitutional Declaration as a Case Study

\section{References}

1. A.Megeid, M. (2010). Challenges are facing media in crises and disasters times. Paper presented in the scientific conference of Sharja University. Emirate: Sharka, p.14

2. Anden-Papadopoulos, K. and Pantti, M. (2013) "The Media Work of Syrian Diaspora Activists: Brokering Between the Protest and Mainstream Media" Paper presented at the annual meeting of the International Communication Association, Hilton Metropole Hotel, London, England Online <APPLICATION/PDF>. 2014-01-07 from http://citation.allacademic.com/meta/p636717_index.html.Retrieved in 14-4-2014.

3. Claeys, A. \&Cauberghe, V. (2012). What makes crisis response strategies work? The impact of crisis involvement and message framing. Journal of Business Research, xx , 2.

4. Claeys, A. \&Cauberghe, V. (2012).Crisis response and crisis timing strategies, two sides of the same coin.Public Relations Review, 38, 84.

5. Coombs, T. (2006).The Protective Powers of Crisis Response Strategies, Journal of Promotion Management, 12(3/4), 246.

6. Coombs, T. \& Holladay, S. (2008). Comparing apology to equivalent crisis response strategies: Clarifyingapology's role and value in crisis communication.Public Relations Review, 34, 252.

7. Dutta, S. \&Pullig, C. (2011). Effectiveness of corporate responses to brand crises: The role of crisis type and response strategies. Journal of Business Research, 64, 1283.

8. Freberg, K. ,Palenchar, M. and Veil, S. (2010). Social Media Bookmarking Services: Managing and Sharing Information from a Centralized Source, Paper presented at the annual meeting of the NCA 96th Annual Convention, San Francisco.http://citation.allacademic.com/meta/p425949_index.html. Retreived in 14-42014.

9. Fisher, B., Austin, L. \& Jin, Y. ( 2011). How publics respond to crisis communication strategies: The interplay of information form and source, Public Relations Review, 37(4), 345 .

10. Golec,A. \&Federico,C. (2004). Understanding Responses to Political Conflict: Interactive Effects of the Need for Closure and Salient Conflict Schemas. Journal of Personality and Social Psychology, 87(6), 750.

11. Grebe, S. (2013). Things can get worse: How mismanagement of a crisis response strategy can cause a secondary or double crisis: the example of the AWB corporate scandal. Corporate Communications: AnInternational Journal, 18 ( 1), 73.

12. Jin, Y., Pang, A. \&Cameron, G. (2010).The Role of Emotions in Crisis Responses Inaugural Test of the Integrated Crisis Mapping (ICM) Model. Corporate Communications: An

13. International Journal, 15 (4),428. 
Crisis Response Strategies of political parties in the Egyptian Social Media- the Constitutional Declaration as a Case Study

14. Sayed, H. (2000). The Role of Media in International Crisis. Cairo: Mahrosa Center, pp. $36-43$.

15. Sisco, H. (2012). The ACORN story: An analysis of crisis response strategies in a nonprofit organization, Public Relations Review, 38, 91.

16. Smith, B. (2010), Socially distributing public relations: Twitter, Haiti and Interactivity in Social Media, Public Relations Review, 36, 329-335.

17. Soliman, S.(2014). Arab Journal of Media and communication Research, July/Sep.3, 155.

18. Vielhaber, M. \&Waltman, J. (2008). Changing Uses of Technology: Crisis Communication Responses in a Faculty Strike. Journal of Business Communication, 45( 3), 311,

19. An, S. (2011). Reducing anger and blame: The role of the morality news frame and crisis response strategy, Public Relations Review 37, 170.

20. Brown, K. \&White, C. (2013). Organization-Public Relationships and Crisis Response Strategies: Impact on Attribution of Responsibility. Journal of Public Relations Research, 23(1), 75 .

21. Liu, B., Austin, L. \& Jin, Y. (2011). How publics respond to crisis communication strategies: The interplayof information form and source. Public Relations Review, 37, 346.

22. Goolsby, R. (2010).Social Media as Crisis Platform: The Future of Community Maps/Crisis Maps. ACM Transitions on Intelligent Systems, 1(1), 7.

23. Sisco, H. \& Erik, C. (2010).7. Behind in the Count: An Examination of Major League Baseball and the Situational Crisis Communication Theory. Paper presented at the annual meeting of the NCA 96th Annual Convention,San Francisco. http://citation.allacademic.com/meta/p426592_index.html. Retrieved in 2.6.2014

24. Soora,K. \& Hoon,S. (2015). Revisiting the effectiveness of base crisis response strategies in comparison of reputation management crisis. Paper presented at the annual meeting of the Association for Education in Journalism and Mass Communication, Renaissance Grand \& Suites Hotel, St.Louis, MO, Aug 10,2011. http://citation.allacademic.com/meta/p520076_index.html. Retrieved in 20.2.2015

25. Veil, S.,Buehner,T. \&Palenchar, M. (2010). "Increasing Dialogue in Disasters: Incorporating Social Media in Risk and Crisis Communication". Paper presented at the annual meeting of the NCA 96th Annual Convention,San Francisco. http://citation.allacademic.com/meta/p420586_index.html. Retrieved in 2.6.2014

26. Shaaban, H.\& Lotfy, M. (2013).The Usages of Social Networks in Mobilizing the Public Opinion during the Emergency Political Crises "Sample: The Crisis of the Egyptian Constitution.Arab Journal of Media and communication Research, July/Sep.(3),294. 